\title{
Famine Foods: Thoughts from a Caatinga Research Experience
}

\author{
Viviany Teixeira do Nascimento and Letícia Zenóbia de Oliveira Campos
}

\section{Contents}

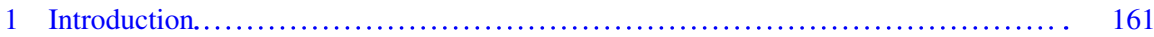

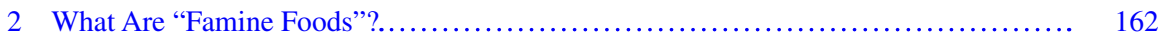

3 What Conditions Favor the Use of Emergency Foods in the Caatinga?............... 164

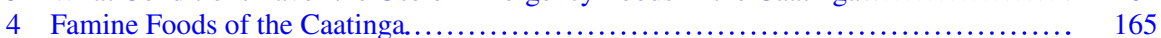

4.1 Anacardiaceae. ................................................... 165

4.2 Apocynaceae..................................................... 165

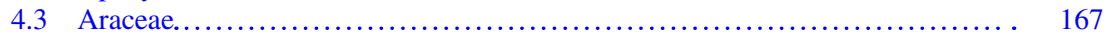

4.4 Arecaceae.................................................. 167

4.5 Bromeliaceae..................................................... 168

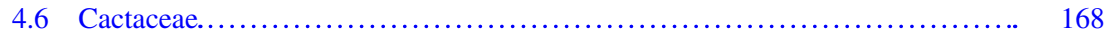

4.7 Dioscoreaceae. ................................................. 169

4.8 Euphorbiaceae.................................................. 170

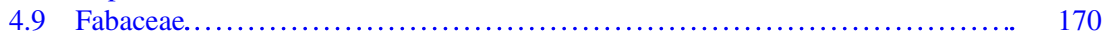

4.10 Menispermaceae............................................. 171

5 Sociocultural Aspects of the Use of "Famine Foods": A Focus on Food Taboos......... 172

6 Final Considerations...................................................... 173

References............................................................... 174

\section{Introduction}

Although eating is a basic human need, food preferences are clearly influenced by the social, political, historical, and economic context in which we live. In addition to these factors, climate issues can temporarily decrease the supply of preferred foods and directly influence what is eaten, causing even the least desirable foods to

\footnotetext{
V. T. do Nascimento $(\bowtie)$

Universidade do Estado da Bahia - UNEB, BR 242, s/n. Loteamento Flamengo.

Departamento de Ciências Humanas, Barreiras, BA, Brazil

e-mail: vtnascimento@uneb.br

\section{Z. O. Campos}

Universidade Federal do Oeste da Bahia - UFOB, Estrada do Barrocão, s/n, Morada Nobre, Barreiras, BA, Brazil
} 
be consumed (Nascimento et al. 2012). When this occurs, we call these foods "emergency foods" or even "famine foods."

Famine foods are those used only in extreme periods, be they native or exotic. These extreme periods are usually linked to environmental factors such as drought, or periods when there is a significant reduction in agricultural production (Eaton and Konner 1985; Guinand and Lemessa 2000). Regardless of the part used, typical famine foods are those that remain in the environment intact for a long period, being accessed only when all other food sources have been consumed (Irvine 1952).

Although these plants are currently used in extreme situations, they merit emphasis because they were for a long time the main source of food for several human populations, and instead of being considered merely complementary, they were essential for the diet (Etkin and Ross 1982; Eaton and Konner 1985; Johns 1990). Specifically in semiarid regions, many of these species guarantee the sustainability of local diets, providing important nutrients for maintaining the health of populations. In this context, traditional populations stand out, as several studies report that there are foods that are actually used, while others are accessed strictly in times of scarcity. This can generate different implications in the selection of certain species that may be used (Cruz et al. 2014; Bravo-Filho et al. 2018). About the Caatinga specifically, a biome that is characterized by vehemently from drought events and where at certain times famine foods become essential.

Several elements can influence this punctuality in relation to the consumption of famine foods, such as the energy expenditure involved in the collection and preparation of food, in addition to the food taboos linked to the social prejudice toward the practice of consuming famine foods. In view of the problem presented, this chapter will bring considerations about the most striking environmental issues that lead to the use of emergency foods in environments such as the Caatinga, the nutritional characterization of species that have already been studied in this perspective, and finally food taboos linked to the consumption of emergency food.

\section{What Are "Famine Foods"?}

Wild food plants are those that are not cultivated, that is, they are collected from natural environments with little human interference and are used to feed people in many regions of the planet, although agriculture represents most of what we eat (Nascimento et al. 2013). Within this group, there are those that are available and are consumed and enjoyed in any season or circumstance. Their importance is such that they are commercialized and sometimes even exported, as is the case with the by-products of the Spondias tuberosa (Anacardiaceae) fruits, a species native to northeast Brazil (Santos et al. 2011). However, there is also a category or subgroup of "wild food plants" whose consumption is only justifiable in periods when favorite foods are unavailable, and they are called "famine foods" or "emergency foods" (Minnis 1991; Muller and Almedom 2008; Jacob and Albuquerque 2020). This subgroup will be addressed in this chapter. 
According to Minnis (1991), plants classified as famine foods must meet two basic assumptions: (1) they must be edible, and (2) they must be available at times when the production and availability of preferred foods is reduced. Therefore, famine foods are usually species well adapted to the most extreme environmental conditions in a given location and resistant to factors such as drought, poor or saline soil, and pests and diseases that can quickly eliminate exotic crops and modern varieties inserted in the local culture by the global market (Minnis 1991; Hughes 2009; Bhansali 2011).

A variety of plant organs can be consumed as famine foods, the most common being the underground organs (roots, rhizomes, tubers, and bulbs), leaves, fruit pulps, seeds, cladodes, or even the entire plant, when it comes to herbs.

In addition to the typical famine foods, occasionally, other sets of plants can gain this status. This is the case of wild plants that have soft parts and do not require a longer time for preparation (usually fruits). They are appreciated and consumed throughout the year, but they have other structures that are usually underground, acting as famine foods. This can also occur with some cultivated plants when parts that are not traditionally consumed are used even if this implies the death of the plant, making it unfeasible for a new harvest cycle (Guinand and Lemessa 2000).

Apart from the types of famine foods explained above, whose parts are only consumed in situations of extreme scarcity, it is noticeable that the literature has associated this name with those wild foods that do not fit as typical famine foods, but that are just not traditionally consumed. That is, they are underutilized foods, but capable of attracting additional consumers in times of scarcity, acting on food and nutrition security, and preventing hunger in times of emergency (Guinand and Lemessa 2000; Hughes 2009).

We must also consider that typical famine foods are often foods that are not actually suitable for food, as they have characteristics that decrease their palatability, such as the presence of thorns. They may taste strange or may be toxic, requiring a prolonged preparation process to reduce their inappropriate properties. Many of these famine foods are low in nutrients, which only help to satiate hunger for a few hours, thanks to their high cellulose content. Finally, they are foods that can be associated with stomach complications, diarrhea, and poisoning. For this set of characteristics, they are commonly considered as a "last resort," used only when all other natural sources of food are exhausted (Castro 1946; Minnis 1991; Guinand and Lemessa 2000).

Although other Brazilian biomes have a number of native and exotic food species that grow spontaneously and can be used as food, they do not meet the basic requirements described above to be categorized as "famine foods." The main characteristic that makes these foods fall into that category is the fact that they are used in periods of extreme drought, where other species are unlikely to be found. For this reason, we selected the Caatinga biome, which has the main characteristics for the consumption of famine foods. After this brief contextualization, we will present below the conditions that lead to the consumption of famine foods by populations in the Brazilian semiarid region, followed by several examples of these resources. 


\section{What Conditions Favor the Use of Emergency Foods in the Caatinga?}

Two ecological characteristics dominate the environmental context of starvation: climatic seasonality and the great dependence of human populations on subsistence and food production systems in the local market. Virtually all naturally occurring famines have occurred in regions that strongly combine seasonal patterns of temperature or humidity with a high degree of variability in these factors from year to year (Cox 1978). In Brazil, the Caatinga is the biome that best fits these conditions.

The Caatinga biome covers the Northeast region of Brazil and some areas of the state of Minas Gerais. It is a region of extreme weather patterns, with high temperatures and high rates of evapotranspiration associated with low relative humidity and precipitation. In this region, a factor that affects the supply of food is the annual distribution of precipitation, as the drought can reach up to 11 months in certain locations (Castro 1946; Nimer 1972). In the longer periods of absence of rain, hunger in the region is widespread, affecting both human and animal populations qualitatively and quantitatively (Castro 1946). This aspect is important because, despite the serious problems in relation to the availability of water and food, the Caatinga is highly populous, with approximately 27 million inhabitants who suffer the effects of the lack of a sustainable food production system (IBGE 2004) ${ }^{1}$

In this semiarid environment of so many uncertainties related to seasonal climatic variability, plants capable of surviving their extreme conditions have adapted. In general, they share the presence of thorns, microphyll, deciduity, and water storage capacity, as observed in cacti and succulents (Prado 2003). This makes the Caatinga region an environment with high rates of floristic endemism that can reach $42 \%$ of succulent and woody species (Prado 2003).

Regarding the plants that can be used for human consumption from this extreme environment, there is a diversity of parts that can be used for this purpose, from leaves, cladodes, flowers, and fruits. In addition, this biome has the lowest per capita income rates in Brazil (IBGE 2004), a factor that directly influences the human populations that live there to depend heavily on natural resources. Different studies that seek to understand this human-plant interrelationship have found that there is a variety of species that can be used, with emphasis on those belonging to the Cactaceae family (Nascimento et al. 2012; Lins-Neto et al. 2013; Cruz et al. 2014; Chaves and Barros 2015; Bravo-Filho et al. 2018). However, most references related to food plants from the Caatinga emphasize only those commonly used. For this reason, we carried out a careful bibliographic review in search of mentions, even if discrete, of the foods used only in times of food scarcity caused by low rainfall and which fall within the concept of emergency foods as described earlier in this chapter.

\footnotetext{
${ }^{1}$ It is important to highlight that in recent years, the lack of food for this significant portion of the population has been mitigated by government policies on access to food that favor the acquisition of products through local commerce throughout the year, but which assume an even more important role relevant in combating hunger in the absence of rain.
} 
Below we will briefly present their chemical composition, preparation methods, and some difficulties related to their consumption.

\section{Famine Foods of the Caatinga}

In Brazil, famine foods have been reported for a long time, although scarcely. In our survey, the oldest yet discreet mentions of this type of food date from the seventeenth century, when the naturalists Piso and Marcgrave prepared a wide inventory of species occurring in northeast Brazil (Piso and Marcgrave 1648). In the past century, a series of works published by the geographer Josué de Castro and collaborators addressed the theme of hunger in Brazil and the food used exclusively in that period (Castro 1946; Castro et al. 1947; Castro 1966). Following these publications, there was an immense silence regarding this type of food, which was only broken in 2012 with the publication of an article with an ethnobotanical focus (Nascimento et al. 2012). It is based on these publications that we will briefly present below the chemical composition, the preparation methods, and some difficulties related to the consumption of certain famine foods. We emphasize that, whenever possible, the species had their Latin names updated according to "Flora 2020". In cases where we did not find the updated Latin name, we left this information clear throughout the text.

\subsection{Anacardiaceae}

Anacardiaceae is a family with a wide variety of food species. For the Caatinga region, the main species found is Spondias tuberosa Arruda (Fig. 1a), a leafy tree native and endemic to Brazil whose fruits and by-products (sweets, jellies, juices, and ice creams) are appreciated inside and outside the northeastern region (Albuquerque and Andrade, 2002; Lins-Neto et al. 2010). For emergency food purposes, the part of this plant consumed is the underground organs. The umbuzeiro root is formed by a spongy parenchyma rich in water (93.3\% humidity), and for this reason, it is often mentioned as an important resource for times of drought (Piso and Marcgrave 1648; Castro 1946; Castro et al. 1947; Pickel 2008; Medeiros and Albuquerque 2014). Another nutritional characteristic of this structure is the presence of ascorbic acid, 13.3 milligrams, which can be an alternative vitamin supplement in times when fruits rich in this substance are unavailable (Castro et al. 1947).

\subsection{Apocynaceae}

Mandevilla tenuifolia (J.C.Mikan) Woodson (Fig. 1b), commonly known as "batata de vaqueiro," is an herbaceous species of the Apocynaceae family, native, but not 


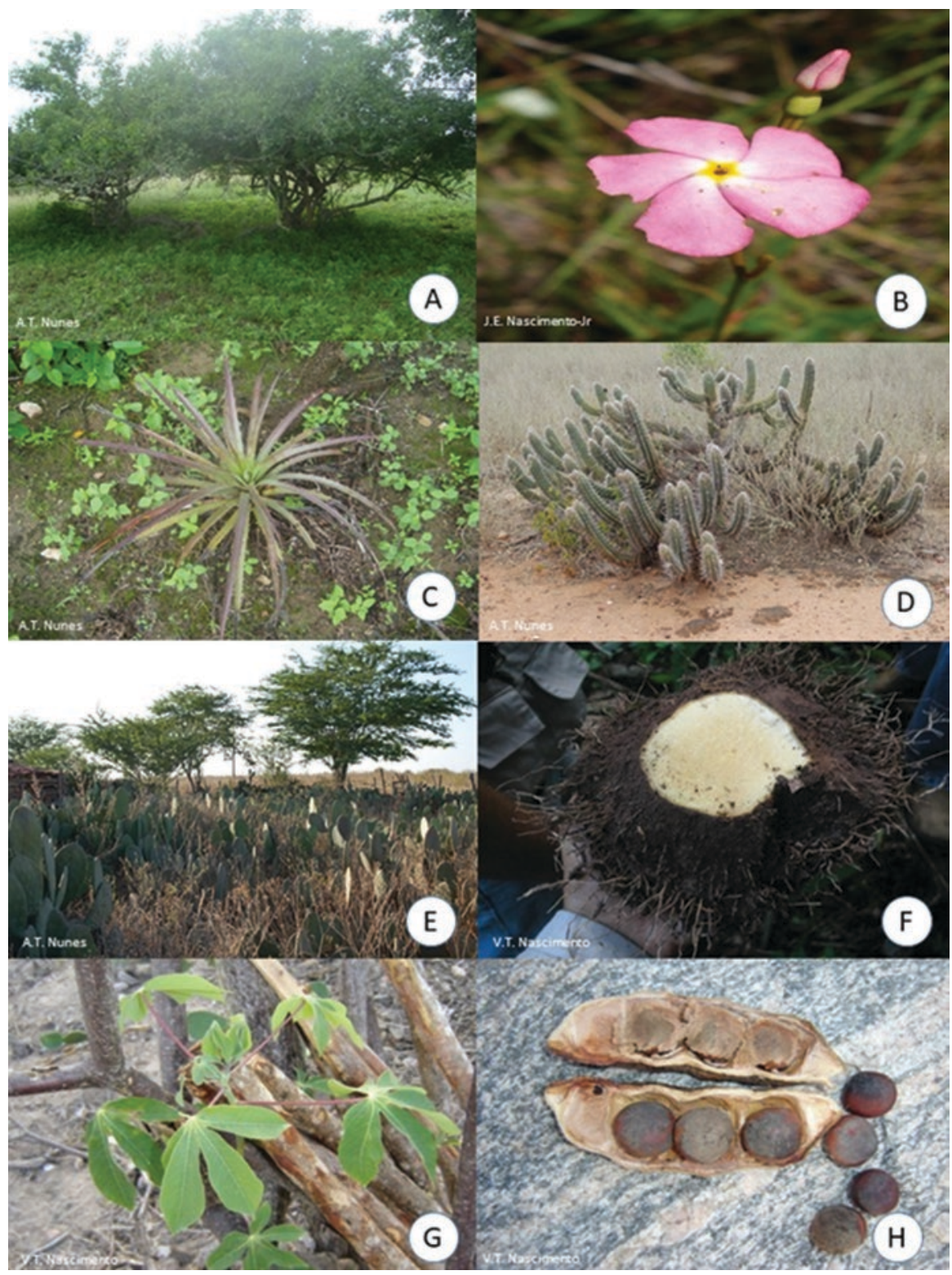

Fig. 1 Some famine foods of the Caatinga region: (a) Spondias tuberosa (plant); (b) Mandevilla tenuifolia (flower); (c) Encholirium spectabile (plant); (d) Pilosocereus gounellei (plant); (e) Opuntia ficus-indica (plant); (f) Dioscorea coronata (tuber); (g) Manihot glaziovii (branches); (h) Dioclea grandiflora (fruit and seeds) 
endemic to Brazil, occurring in different phytogeographic domains including the Caatinga (Koch et al. 2015). In this region, it blooms soon after the first rains, thanks to the presence of an underground organ (xylopodium) that guarantees survival during the dry season. When full of water, the xylopodium becomes edible and is collected and consumed fresh without any kind of preparation similar to a vegetable while the products of the next harvest are not yet available. Thus, the organ is considered an emergency food. Nutritional analysis of xylopodium revealed that it has a low caloric value $(63.2 \mathrm{~g} / 100 \mathrm{~g})$ and a large amount of water. Toxic effects related to food consumption of this species are unknown (Nascimento et al. 2012).

\subsection{Araceae}

Montrichardia linifera (Arruda) Schott commonly known as "aninga" is a nonendemic herbaceous Araceae from Brazil that occurs in the Amazon, Atlantic Forest, and Caatinga (Mayo and Andrade 2020). Its use as a useful food to suppress hunger was recorded on naturalist treaties from the seventeenth century. The edible part is the fruit, which can be eaten fresh or made into flour. According to reports, the ingestion of this species causes everything from simple flatulence to respiratory complications that can lead to death (Piso and Marcgrave 1648; Pickel 2008; Medeiros and Albuquerque 2014). Despite this, it is noticeable for its high caloric value, about $355 \mathrm{kcal} / 100 \mathrm{~g}$, mainly from carbohydrates $86.5 \mathrm{~g} / 100 \mathrm{~g}$. Minerals such as calcium, iron, and zinc were also recorded in the nutritional analysis of this species (Amarante et al. 2010).

\subsection{Arecaceae}

Three species of this family have been reported as food in times of scarcity. The oil of the fruit of Syagrus comosa (Mart.) Mart. "coco amargoso" (basionym Cocos comosa Mart. reported in Castro et al. 1947 and Castro 1966) has a chemical composition (67.3 g/100 g lipids and $9.5 \mu \mathrm{g} / 100 \mathrm{~g}$ calcium), odor, and taste very similar to Cocos nucifera oil (coco da bahia) and can be used as substitute for this. Despite these similarities, we believe that the use of this oil only as an emergency food is related to the small size of the fruits of $S$. comosa, which makes its preparation difficult. Thus, it is disregarded in the face of $C$. nucifera oil, which is easier to prepare due to the size of the fruits.

Other species of the Arecaceae family that have been identified as emergency food are Copernicia prunifera (Mill.) H. E. Moore (syn. Copernicia cerifera mentioned by Castro 1946 - "macaubeira") and Cocos mucronata (mentioned by Castro 1946, "oricuri"). The stem of the first species is used in the form of heart of palm, while the same organ of the second species is grated and cooked to prepare a poor nutritional quality bread, known as "sinister bread," which only fill one's belly, but 
does not suppress hunger. This bread was first mentioned in the literary work $O s$ Sertões by Euclides da Cunha, published in 1902. However, the author did not mention the scientific name of the species. Then, Castro (1946) gave it the name C. mucronata, as mentioned above. However, we did not find this species, nor the update of its scientific name in "Flora 2020," which causes uncertainty about the scientific name of this emergency food.

\subsection{Bromeliaceae}

The Bromeliaceae family is present throughout Brazil, occurring in all biomes. Some species of this family are referred to in the literature as emergency food. This is the case of Bromelia laciniosa Mart. ex Schult. \& Schult.f. (Castro et al. 1947) and Encholirium spectabile Mart. ex Schult. \& Schult.f. (Fig. 1c) commonly known as "macambira" (Castro 1946; Nascimento et al. 2012). Both species are abundant and endemic to the Caatinga region. The bulb is the organ consumed as an emergency food. The collection of these Bromeliaceae adds difficulty to their consumption since they have leaves with many thorns on the margin. For it to be served as food, the bulb is cooked and then sun-dried. Once dried, the organ is crushed to make some flour from which couscous is prepared. No toxic effect associated to the flours of these Bromeliaceae is known. From the nutritional point of view, both have considerable caloric value. B. laciniosa has about $118 \mathrm{kcal} / 100 \mathrm{~g}$ of product (Chaves et al. 2015), while E. spectabile has $124 \mathrm{kcal} / 100 \mathrm{~g}$. In both cases, most of this caloric value is related to carbohydrates, since in both species, the values of lipids and proteins are low (Castro et al. 1947; Nascimento et al. 2012; Chaves et al. 2015). B. laciniosa also has thiamine, about $168 \mu \mathrm{g} / 100 \mathrm{~g}$ of flour (Castro et al. 1947), and is considered exceptionally rich in calcium (Castro 1946).

Another Bromeliaceae that is also mentioned as an emergency food is Bromelia karatas "caraguatá-acanga" (Castro 1966). However, the most recent botanical reviews "Flora 2020" consider that this species does not occur spontaneously in Brazil, which leads them to believe that some identification problem occurred at the time of the publication of Castro's work (1946).

\subsection{Cactaceae}

The Cactaceae family is among the most important ones when it comes to emergency food in the Caatinga, thanks to its ability to face long periods of drought. One of the species used for this purpose is Pilosocereus gounellei (F.A.C.Weber) Byles \& Rowley "xiquexique" (Fig. 1d), a shrub cactus occurring only in Brazil (Zappi et al. 2015). It is a species used mainly for animal consumption (Brito Cavalcanti and Milanez 2007). However, humans consume it when drought worsens. In this situation, the cladodes are cut, and their abundant thorns are removed together with 
a water storage tissue typical of Cactaceae. The cuts are made until a woody chamber that protects a marrow is reached. The chamber is then cooked or roasted for a few minutes over fire and then removed with a knife, leaving only the marrow that can be immediately consumed or transformed into flour used to prepare the couscous. The preparation of this emergency food is difficult due to the presence of thorns; its nutritional yield is low, yielding only $27.5 \mathrm{kcal} / 100 \mathrm{~g}$ of product; and toxic properties related to its consumption are unknown (Nascimento et al. 2012).

Cereus setosus and Pilocerius setosus (also known as xiquexique) are other cacti mentioned by Castro (1946) and Castro et al. (1947), respectively, as emergency food. The useful parts, method of preparation, and nutritional composition are similar to those of $P$. gounellei described above. However, we cannot confirm the current identification of the species according to the most recent botanical reviews, since both were not mentioned in "Flora 2020." Thus, we do not know which species the publications mentioned above refer to.

Within the Cactaceae family, Opuntia ficus-indica (L.) Mill "palma forrageira" (Fig. 1e) needs to be addressed, a species that has its origin in Mexico but is currently considered naturalized in Brazil (Zappi et al. 2015). Despite being introduced in the country since the first years after the arrival of the Europeans, the plant had its cultivation encouraged in the northeast region in the beginning of the 1930s, right after a great drought that occurred in 1932. At the time, the purpose was to use it as food for farm animals (Duque 1980).

O. ficus-indica has been little addressed in ethnobotanical surveys focused on food plants, as it is not originally from Brazil. However, our experience in different communities in the Caatinga allows us to affirm that the plant is one of the first to be mentioned when talking about emergency foods these days. The organ consumed is the cladode known as rackets, from which the thorns are removed and then chopped and cooked for human consumption. Toxic effects related to their intake are unknown (personal observations of the authors). Cladodes are an important source of water, carbohydrates, fibers, proteins, lipids, and minerals such as calcium, as well as antioxidants (Stintzing and Carle 2005; Bensadón et al. 2010; Silva et al. 2015), and are considered a noble food in other countries. However, in the northeast region of Brazil, its human use is seriously prejudged, probably due to its widespread use as animal food (Cantwell 2001).

\subsection{Dioscoreaceae}

The tuber of the vine Dioscorea coronata Hauman "pinanga de coroa" (Fig. 1f) is an organ that can be used as an emergency food. The structure is collected and consumed after cooking, which helps not only to soften but also to reduce its bitter taste. No health problems attributed to its consumption were recorded, but the caloric value for each $100 \mathrm{~g}$ of product is as low as $73.6 \mathrm{~g} / 100 \mathrm{~g}$. It has less than $1 \%$ protein and approximately $17 \mathrm{~g}$ of carbohydrates (Nascimento et al. 2012). 


\subsection{Euphorbiaceae}

Within this family, two species are used as emergency food, Manihot dichotoma Ule "maniçoba" and Manihot glaziovii Müll.Arg. "purnunça" (Fig. 1g) (Nascimento et al. 2012), known as wild cassava. The edible part of both species in times of food scarcity is the tuberous roots. To be consumed, the raw organ needs to be washed several times to eliminate its toxic properties that can cause a range of effects, from dizziness to death. After proper washing, the roots can be cooked or toasted to be used later in the preparation of flour, beijus, cakes, porridge, etc. M. dichotoma and M. glaziovii have 104 and $79 \mathrm{kcal} / 100 \mathrm{~g}$ of product, respectively, most of which are attributed to carbohydrates ( 24 and $18 \mathrm{~g} / 100 \mathrm{~g}$ ). Although lower than the caloric value of conventional cassava (Manihot esculenta Crantz) (Bezerra and Saldanha, 2002), we believe that if their toxic properties are properly eliminated, $M$. dichotoma and $M$. glaziovii can be important emergency foods, helping populations when food from conventional crops are temporarily unavailable.

\subsection{Fabaceae}

The Leguminosae are considered the most important source of emergency food for the population of the Caatinga, due to the number of species listed as useful for this purpose. Some plants, popularly called Mucuna, have very similar forms of preparation and problems caused by their ingestion. Some examples are Dioclea grandiflora Mart. ex Benth (Fig. 1h) (Nascimento et al. 2012), Mucuna urens (L.) Medik. (Castro 1946), and Mucuna glabra (Reinecke) Wilmot-Dear. The latter was cited by Castro et al. (1947) and Castro (1966); however this species currently has no resolved scientific name, which makes it difficult to know which species the author was referring to at the time of publication.

D. grandiflora and M. urens are native vines of Brazil, although only the first is considered endemic to the Caatinga. The organs consumed from D. grandiflora as an emergency food are the seeds, while the roots are consumed from $M$. urens in addition to the seeds. Both organs are used for the preparation of a flour that will later be transformed into couscous. The flour produced from the seeds of D. grandiflora has a high caloric value, around $367 \mathrm{kcal} / 100 \mathrm{~g}$, due to its high levels of proteins $(30.9 \mathrm{~g} / 100 \mathrm{~g})$ and carbohydrates $(54.3 \mathrm{~g} / 100)$ (Nascimento et al. 2012). The same is observed for $M$. urens, with $28.5 \%$ proteins and $54.6 \%$ carbohydrates in addition to calcium, iron, and vitamin B1 (Castro 1946). The nutritional value of these species is up to five times greater than that of Vigna unguiculata (L.) Walp. (Beans or feijão de corda as known locally) (Taco 2011), another Leguminosae traditionally consumed in northeast Brazil. These results were taken into account to categorize D. grandiflora and $M$. urens as two important emergency foods in the Caatinga region, the cultivation of which should be encouraged and the use applied to other times of the year. 
However, it is worth noting that the consumption of both D. grandiflora and M. urens flours is usually associated with different stomach disorders and other problems such as the suspension of menstruation and swelling of the skin, and in more extreme cases, ingestion may lead to death. It is customary to wash the flour numerous times before consumption to alleviate such toxic effects, a treatment that according to users does not eliminate all the toxicity attributed to plants (Castro 1946; Nascimento et al. 2012). However, Castro (1946) considers such symptoms to be a myth, linked much more to the advanced state of malnutrition of the population than the toxicity of the plant. To justify this theory, Castro et al. (1947) tested the flour from the seeds of M. glabra and confirmed that it was an innocuous product. However, we must be careful with this statement because the species used in this experiment was precisely the one with unknown updated Latin name, and therefore it is impossible to extrapolate the results obtained for D. grandiflora and M. urens without further studies being undertaken.

Castro (1946) mentioned two more Leguminosae that are used in times of food shortage: Tipuana tipu (Benth.) Kuntze (updated name of Tipuana especiosa) "pau de mocó," a non-endemic native shrub distributed throughout Brazil (Lima 2015), and Senna occidentalis (L.) Link (updated name of Cassia occidentalis), a tree popularly known as "fedegoso" (Bortoluzzi et al. 2020). A flour used to make porridge is usually produced with the roots of T. tipu, while the seeds of $S$. occidentalis are roasted to make coffee. For both species, we did not obtain information about the nutritional value or any toxic effect related to their consumption.

Another species of this family consumed in times of famine is Geoffroea spinosa Jacq. (Tomchinsky and Ming 2019), "umarizeiro," a non-endemic native tree occurring in the Caatinga (Penington 2015). The plant has fruits that, when eaten fresh, cause stomach problems that are only relieved when they are cooked and subsequently macerated. The cream resulting from this preparation can be consumed with meat or fish, replacing bread (Piso and Marcgrave 1648; Pickel 2008; Medeiros and Albuquerque 2014).

\subsection{Menispermaceae}

Abutua platyphylla, parreira-brava, name not found in "Flora 2020," is a species whose fruits resemble grape clusters, although these are not edible. The part of this vine consumed as an emergency food is the root, from which a flour low in protein and vitamins can be produced (Castro et al. 1947). In its composition stands out thiamine content of $22.5 \mu \mathrm{g} / 100 \mathrm{~g}$ and high starch content of 50.3\%/100 g. Information regarding the preparation of the flour or the presence of problems caused by ingestion of the species was not found (Castro et al. 1947; Castro 1966). 


\section{Sociocultural Aspects of the Use of "Famine Foods": A Focus on Food Taboos}

Despite the context of scarcity of food resources for the populations living in the semiarid regions of Brazil, in times when there is a drastic decrease in the rainfall regime, there are species, such as those listed above, that can be used in such a situation. However, the fact that there is a resource available does not imply its use, since preferences or not for certain foods are rooted in social and cultural matters (MacBeth and Lawry 1997).

When social and cultural questions about the use of a plant are shared between members of a group, they can become food taboos, which act as social markers to show differences between individuals and groups, influence attitudes and behaviors, and facilitate the functioning of systems (Garine 1995). In relation to famine foods, food taboos are mainly linked to the scarcity of financial resources of human populations, leading to a social prejudice toward the use of these foods. These prejudice views often do not take into account the nutritional value of the species because, as demonstrated in the previous topic, many plants have a considerable nutritional value.

Josué de Castro in his work The Geography of Hunger, issued in 1946, pointed out that cultural issues and beliefs carried by our ancestors and, consequently, passed on to future generations influence the eating practices that we adopt throughout our trajectory. A classic example is the high consumption of farinaceous foods by populations of northeast Brazil, a practice encouraged by our colonizers, in which the consumption of more nutritious and available foods in the region gradually decreased (Castro 1946).

Another aspect that we consider relevant to determine the low use of emergency food in the Caatinga region, a real taboo, is the fact that many of these plants are used frequently for animal feeding. Thus, those who need to consume such food may feel equivalent to animals. This often leads them to deny the fact that they are consuming such food or even that they have already consumed them at some point in their lives (personal observations of the authors).

This trend of low consumption of native foods, emergency foods or not, is not seen in other regions of the world, especially in countries that have an arid climate, such as those on the African continent (Okigbo 1975; Ogle and Grivetti 1985; Campbell 1986). In this sense, we can mention some examples such as southeastern Nigeria, where leaves and fruits of different native species are used in times of famine (Okigbo 1975). In the region of Swaziland, Ogle and Grivetti (1985) reported the use of more than 200 species of wild plants that are commonly consumed. Wachiira (1987), in a study carried out in Kenya, found that native leaves and fruits contribute significantly to the diet and that many emergency plants are consumed mainly by children. In regions close to native forests in Zimbabwe, Campbell (1986) found that wild fruits are consumed only in periods of scarcity and when there is a decrease in agricultural work, a behavior that is comparable to that found in the populations of the Brazilian semiarid region. 
Given this context of low utilization of wild food plants and particularly famine foods, consumers and policy makers may not be aware of the benefits that underutilized plants can offer, which results in little attention to their conservation, crop improvement, nutritional assessment, production technologies, and post-harvest handling and promotion or marketing (Hughes 2009). In relation to this trend of famine foods being accessed only in times of scarcity, the World Vegetable Center (WVC) has been working to recognize the potential that these foods have in alleviating poverty and malnutrition in developing countries, especially those located in Africa (Hughes 2009).

Another discussion related to the use of "famine foods" is linked to the palatability. In this sense, Crúz et al. (2014) reported that one of the factors that often interfere in the selection of a native species for food is precisely the taste, as well as the preparation time that is required to neutralize components that can interfere in the palatability resulting in bitter taste or undesired texture, for example. Another issue also described about the use of certain species is linked to their morphological characteristics. Often, there are plants with thorns that need a long period of preparation to be consumed. Chaves and Barros (2015), in their study on the consumption of Cactaceae, revealed that the most used parts of the species are cladodes, followed by fruits and flowers. A large part of the cladodes are used to make flour, which demands a fair amount of time for its preparation, making this practice very unusual nowadays. Therefore, considering the cost-benefit of the collection, treatment and cooking activities (nutritional value - energy), these species end up not being consumed in times when there are other resources that are easier to be found, prepared, and used.

Finally, the new model of social and economic development imposed by modern society may have a negative influence on the consumption of traditional foods, since there is an ease in acquiring products in the food markets that would take a long time to be prepared manually at home (Crúz et al. 2014). The purchase of these foods is often only possible, thanks to the financial support given to the populations by government agencies and international agencies to fight hunger (Minnis 1991; Nascimento et al. 2012), which can pose a problem if such support is deficient. Furthermore, we believe that this financial contribution can interrupt the flow of knowledge between generations, leaving information about famine foods restricted to older individuals in the localities (Nascimento et al. 2012), while younger people are not interested in having such knowledge because they prefer to buy the food.

\section{Final Considerations}

Considering the aspects brought up in this chapter, we understand the high importance that famine foods had at different periods for human populations and how valuable they can be to alleviate hunger in emergencies. However, the absence of studies that report this issue can lead to the discontinuity of the different practices related to the use of these foods, and, if in some time they are necessary, the populations need to relearn how to use them. Thus, it is important that the knowl- 
edge about these practices is not restricted to the elderly and that the improvement of the socioeconomic conditions of the populations does not interfere in the knowledge related to the practices of use famine foods. For this, it is important that the stigma of poverty is considered in the different local communities of the Caatinga, because the use of any species to supply a basic need cannot be a matter of shame for any population. However, there is a historical prejudice paradigm in this issue; thus actions to popularize the use of these resources may play an important role. This can help to de-mystify the practice that famine foods are animal food and that, if people feed on them, they will be equated to animals. Finally, we believe that studies on famine foods are important so that they can be used beyond local areas and commercialized, and thus, we must ensure that knowledge about these practices is maintained so that there is resilience in socioecological systems.

\section{References}

Albuquerque UP, Andrade LHC (2002) Conhecimento botânico tradicional e conservação em uma área de caatinga no estado de Pernambuco, Nordeste do Brasil. Act Bot Bras 16:273-285. https://doi.org/10.1590/S0102-33062002000300004

Amarante, CB, Müller RCS, Dantas, KGF et al (2010) Composição química e valor nutricional para grandes herbívoros das folhas e frutos de aninga (Montrichardia linifera, Araceae). A Amaz 40(4): 729-736

Bensadón S, Hervert-Hernández D, Sáyago-Ayerdi SG et al (2010) By-products of Opuntia ficus-indica as a source of antioxidant dietary fiber. P Food H Nut 65(3):210-216. https://doi. org/10.1007/s11130-010-0176-2

Bezerra VS, Saldanha VSB (2002) Valor Nutricional da Mandioca (Manihot esculenta Crantz) e Transformações Pós-Colheita. Macapá: Embrapa Amapá. 18p. ; 21 cm (Embrapa Amapá. Documentos, 36)

Bhansali RR (2011) Famine foods in the Rajasthan Desert. Ec Bot Desert Plants (28):73-81. https://doi.org/10.1007/BF02861383

Bortoluzzi RLC, Lima AG, Souza VC, Rosignoli-Oliveira LG, Conceição AS (2020) Senna in Flora do Brasil 2020. Jardim Botânico do Rio de Janeiro. http://floradobrasil.jbrj.gov.br/ reflora/floradobrasil/FB23149. Accessed March 14, 2021.

Bravo Filho ES, Santana MC, Santos PAA et al (2018) Levantamento etnobotânico da família Cactaceae no estado de Sergipe. R Fitos. https://doi.org/10.5935/2446-4775.20180005

Brito Cavalcanti N, Milanez G (2007) Consumo de Xiquexique (Pilocereus gounellei (A. Weber ex K. Schum.) Bly. ex Rowl) por caprinos no semi-árido da Bahia. R Caatinga (20) 1

Campbell BM (1986) The importance of wild fruits for peasant households in Zimbabwe. F Nut 12(1):38-44

Cantwell M (2001) Manejo pós-colheita de frutas e verdura de palma forrageira. In: Barbera G, Inglese P (eds) Agroecologia, cultivos e usos da palma forrageira. SEBRAE/PB, Paraíba, pp 20-27

Castro J (1946) Geografia da fome. Editora Brasiliense, $9^{a}$ edição, 1996. São Paulo

Castro J, Pechnik E, Parahim O et al (1947) Os "Alimentos bárbaros" dos sertões do Nordeste. Arquivos Brasileiros de Nutrição 3(2):5-29

Castro J (1966) Death in the Northeast. Random House, New York

Chaves EMF, Barros RFM (2015) Cactáceas: recursos alimentar emergencial no semiárido, Nordeste do Brasil. G Scient 9(2):129-135 
Chaves EMF, Silva JN, Lima A et al (2015) Potential of wild food plants from the semi-arid region of northeast Brasil: chemical approach ethnoguided. Revista Espacios 36(16)

Cox GW (1978) The ecology of famine: an overview†. E Food Nut 6(4):207-220. https://doi.org/ 10.1080/03670244.1978.9990500

Crúz MP, Medeiros PM, Comarizao IS et al (2014) "I eat the manofe so it is not forgotten": local perceptions and consumption of native wild edible plants from seasonal dry forests in Brazil. J Ethnobiol Ethnomed 10:45. https://doi.org/10.1186/1746-4269-10-45

Duque SG (1980) O Nordeste e as culturas xerófilas. Mossoró: 3. ed. Escola Superior de Agricultura de Mossoró/Fundação Guimarães Duque. ESAM (Coleção Mossoroense,143). 316p

Eaton SB, Konner M (1985) Paleolithic nutrition a consideration of its nature and current implications. T. N Engl J Med 31(5). https://doi.org/10.1056/nejm198501313120505

Etkin N, Ross PJ (1982) Food as medicine and medicine as food. An adaptive framework for the interpretation of plant utilization among the Hausa of northern. Nigeria S Sc and Med 16(17):1559-1573. https://doi.org/10.1016/0277-9536(82)90167-8

Flora do Brasil (2020) in construction. Jardim Botânico do Rio de Janeiro. Available from: http:// floradobrasil.jbrj.gov.br/. Accessed July 23, 2020

Garine I (1995) The diet and nutrition of human populations. In: Ingolg T (ed) Companion Encyclopedia of anthropology. Routledge, London, pp 226-264

Guinand Y, Lemessa D (2000) Wild-food plants in Ethiopia: reflections on the role of wild foods and famine foods at a time of drought. In: Kenyatta C, Henderson A (eds) The potential of indigenous wild foods. USAID/OFDA, CRS/Southern Sudan, pp 31-46

Hughes J (2009) Just famine foods? What contributions can underutilized plants make to food security? Acta Hortic (806):39-48. https://doi.org/10.17660/ActaHortic.2009.806.2

Instituto Brasileiro de Geografia e Estatística. Mapa de biomas do Brasil [Internet]. IBGE. 2004 [cited 2020 Maio 20]. Available from: https://ww2.ibge.gov.br/home/presidencia/ noticias/21052004biomashtml.shtm. Accessed June 30, 2020

Irvine FR (1952) Supplementary and emergency food plants of West Africa. Ec Bot 6:23-40. https://doi.org/10.1007/BF02859192

Jacob MCM, Albuquerque UP (2020) Biodiverse food plants: which gaps do we need to address to promote sustainable diets? Eth Conserv 9:9. https://doi.org/10.15451/ec2020-04-9.09-1-6

Johns T (1990) Human perception, cognition, and behavior in relation to plant chemicals. In: Johns $\mathrm{T}$ (ed) The origins of human diet and medicine. The University of Arizona Press, pp 160-194

Koch I, Rapini A, Simões AO et al (2015) Apocynaceae in Lista de Espécies da Flora do Brasil. Jardim Botânico do Rio de Janeiro. http://floradobrasil.jbrj.gov.br/jabot/floradobrasil/FB4676. Accessed June 15, 2020

Lima HC (2015) Tipuana in Lista de Espécies da Flora do Brasil. Jardim Botânico do Rio de Janeiro. http://floradobrasil.jbrj.gov.br/jabot/floradobrasil/FB23206. Accessed March 14, 2021.

Lins Neto EMF, Peroni N, Albuquerque UP (2010) Traditional knowledge and management of umbu (Spondias tuberosa Anacardiaceae): an endemic species from the semi-arid region of Northeastern Brazil. Ec Bot 64(1):11-21. https://doi.org/10.1007/s12231-009-9106-3

Lins Neto EMF, Almeida ALS, Peroni N et al (2013) Phenology of Spondias tuberosa Arruda (Anacardiaceae) under different landscape management regimes and a proposal for a rapid phenological diagnosis using local knowledge. J Ethnobio Ethnomed 9:10. https://doi. org/10.1186/1746-4269-9-10

MacBeth H, Lawry S (1997) Food preferences and taste: an introduction. In: Macbeth H (ed) Food preferences and taste: continuity and change, Anthropology of Food \& Nutrition. Berghanhn Books, pp 1, 236-14

Mayo SJ, Andrade IM (2020) Montrichardia in Flora do Brasil 2020. Jardim Botânico do Rio de Janeiro. Available from:. http://floradobrasil.jbrj.gov.br/reflora/floradobrasil/FB5013. Accessed March 14, 2021.

Medeiros MFT, Albuquerque UP (2014) Food flora in 17th century northeast region of Brazil in Historia Naturalis Brasiliae. J Ethnobio Ethnomed 10:50 
Minnis PE (1991) Famine foods of the Northern American Desert Borderlands in historical context. J Ethnobiol 11(2):231-257

Müller JG, Almedom A (2008) What is "Famine Food"? Distinguishing between traditional vegetables and special foods for times of hunger/scarcity (Boumba, Niger). H Ecol 36(4):599-607. https://doi.org/10.1007/s10745-008-9179-0

Nascimento VT, Vasconcelos MAS, Maciel MIS et al (2012) Famine foods of Brazil's seasonal dry forests: ethnobotanical and nutritional aspects. Ec Bot 66(1):22-34. https://doi.org/10.1007/ s12231-012-9187-2

Nascimento VT, Lucena RFP, Maciel MIS et al (2013) Knowledge and use of wild food plants in areas of dry seasonal forests in Brazil. E Food Nut 52:1-26. https://doi.org/10.1080/0367024 4.2012.707434

Nimer E (1972) Climatologia da região Nordeste do Brasil: introdução à climatologia dinâmica. R Bras de Geo 34:3-51

Ogle BM, Grivetti LE (1985) Legacy of the chameleon. Edible wild plants in the Kingdom of Swaziland, southern Africa: a cultural, ecological and nutritional study. Eco Food Nut, in four parts 16(3):193-208, Parts II-IV: 17(11): 1-64. https://doi.org/10.1080/03670244.1985.99908 81

Okigbo BN (1975) Neglected plants of horticultural and nutritional importance in traditional farming systems of tropical West Africa. Acta Hortic 53:131-150. https://doi.org/10.17660/ ActaHortic.1977.53.18

Prado, DE (2003) As Caatingas da América do Sul. In: Ecologia e conservação da caatinga / editores Inara R. Leal, Marcelo Tabarelli, José Maria Cardoso da Silva.; prefácio de Marcos Luiz Barroso Barros. - Recife : Ed. Universitária da UFPE 822 p

Pennington T (2015) Geoffroea in Lista de Espécies da Flora do Brasil. Jardim Botânico do Rio de Janeiro. http://floradobrasil.jbrj.gov.br/jabot/floradobrasil/FB22792. Accessed June 20, 2020

Piso W, Marcgrave G (1648) In Historia Naturalis Brasiliae: in qua non tantum plantae et animalia, sed et indigenarum morbi, ingenia et mores describuntur et iconibus supra quingentas illustrantur. Edited by de Laet J. Amsterdam: Elsevier; 1648. http://biblio.etnolinguistica.org/ marcgrave-1648-historia. Accessed June 22, 2020

Pickel BJ (2008) Flora do Nordeste do Brasil segundo Piso e Marcgrave : no século XVII / Argus Vasconcelos de Almeida (Editor). - Recife: EDUFRPE, $312 \mathrm{p}$

Santos MB, Cardoso RL, Fonseca AAO et al (2011) Caracterização e qualidade de frutos de umbucajá (Spondias tuberosa X.S. mombin) provenientes do Recôncavo Sul da Bahia. Rev Bras Frutic 32(4):1089-1097

Stintzing FC, Carle R (2005) Cactus stems (Opuntia spp.): a review on their chemistry, technology, and uses. M Nut Food Res 49(2):175-194. https://doi.org/10.1002/mnfr.200400071

Silva AP, Souza CCE, Ribeiro JES et al (2015) Características Físicas, Químicas e Bromatológicas de Palma Gigante (Opuntia ficus-indica) e miúda (Nopalea cochenillifera) Oriundas do Estado da Paraíba. Revista Brasileira de Tecnologia Agroindustrial 9(2)

Tomchinsky B, Ming LC (2019) As plantas comestíveis no Brasil dos séculos XVI e XVII segundo relatos de época. Rodriguésia doi:DOI:dx.doi.org/10.1590/2175-7860201970040

Universidade Estadual de Campinas. Tabela brasileira de composição de alimentos - TACO. UNICAMP/NEPA, $4^{\mathrm{a}}$ ed., 2011. Campinas

Wachiira KK (1987) Women's use of off-farm and boundary lands: agroforestry potentials. Final report. ICRAF, Nairobi, p 139

Zappi D, Taylor N, Santos MR et al (2015). Cactaceae in Lista de Espécies da Flora do Brasil. Jardim Botânico do Rio de Janeiro http://floradobrasil.jbrj.gov.br/jabot/floradobrasil/FB1663. Accessed June 02, 2020 